\title{
Writing in Arabic as a Foreign Language (AFL): Towards Finding a Balance between Translation Dependency and Creative Writing
}

\author{
Zouhir Gabsi \\ Deakin University, Melbourne, Australia
}

\begin{abstract}
The main objective of the paper is to assess the effect of Google translation and other software applications on the students' writing in Arabic as a Foreign Language (AFL). Its central hypothesis hinges on the possibility that some students' errors are attributable to translation mishaps. The research is based on three main areas of enquiry: first; it seeks to establish patterned input when writing in Arabic, such as a semantic transfer from English to Arabic and literal translation. Second, the paper discusses those areas of the Arabic language that challenge the students' inability to provide a correct TL (Target Language) output on the levels of morpho-syntax, semantics, and pragmatics. Third, the paper argues for the importance of teaching the rudiments of translation at the early stages of language learning. Hence, it proposes solutions and empirical strategies to reducing the students' reliance on translation by, for instance, educating them about the translation process, and by designing guided writing tasks with rehearsed structures, and without discouraging creativity.
\end{abstract}

Index Terms-Arabic as a foreign language, translation, google translation, second language acquisition, language teaching

\section{INTRODUCTION}

With the advance in technology, non-native speakers of Arabic rely heavily on various online tools and computer applications (such as translation through Word) to assist them with their writing tasks. For this study, the paper uses the term 'machine translation' (MT) to refer to any non-human translation. The students' motivation behind relying on 'machine' translation is predictable because either they aim at reducing errors in their writing or, they lack the linguistic skills in the target language (Arabic). However, since these students are not familiar with the complexities of the Arabic language in terms of sentential structures and rhetoric, they may fall in the trap of literal translation.

The productive skill of writing is inherently difficult to a non-native speaker of Arabic. Writing can cause anxiety among students of L2, as it is "an emotional as well as cognitive activity" (Cheng, 2002, p. 647). The writer, in this case the student, needs not only possess the grammatical rules in the text's production but also he/she needs to be familiar with the subtleties and nuances of language. Writing differs from spoken discourse. ${ }^{a}$ These differ on several fronts, and among these: 'permanence', 'explicitness', 'density', 'detachment', 'organization', and the use of standard language (Ur, 1991, p. 161).

Probably the most relevant of these to the translation process is 'detachment' and 'explicitness'. Detachment is understood in terms of 'time' and 'space' where the writer or translator might know his/her reader. By explicitness, the writer needs "to make clear the contexts and all references" (Ur, 1991, p. 161).

Writing in Arabic for a student whose English is a first language presents many challenges. Linguistically, the sentence in Arabic has more flexibility than its English counterpart, one finds possible structures such as VSO, SVO, VOS, and OVS, but this structural 'freedom' is bound by grammatical notions of 'case' and topicalization. Though case or the marking of the last letter in nouns in not shown when writing MSA, it does not lead to misunderstanding (Holes, 2004, p. 251). This is because there is a normal word order for MSA that is determined primarily by a principle organization: what is already "known" from the previous text or context) and is usually grammatically definite) precedes what is "new" (and is usually indefinite), regardless of whether what is known /definite is the grammatical subject or object.

A close analysis of the students' writing in Arabic reveals both grammatical and lexical problems. And the complex nature of the pronouns system in Arabic (12 against 8), the Idhafa structure (annexation), subject-verb agreement, and case present some of the main challenges when writing in Arabic. Even lexically, students overlook the variance between words and overgeneralise its uses. Translation through MT does not constellate word meanings compared to dictionaries.

Writing in Arabic becomes even a more challenging task when the student uses online tools for the translating of words, sentences, or even chunks of texts. In the translation process from English to Arabic, the student or 'amateur'

\footnotetext{
${ }^{a}$ See Halliday, M.A.K. 1985. Spoken and Written Language. Oxford: Oxford University Press.
} 
translator is unaware of the imperfections of online translation tools, which provide mainly decontextualized translations with no consideration of audience or purpose in mind.

Hence, inevitably writing and its link with translation should be considered when designing language programs such as in SLA (Second Language Acquisition) and the teaching of foreign languages.

The paper aims to answer three critical questions; first, what grammatical and stylistic aspects of students' reliance on MT can be evidenced in their writing? Second, how the skill of translation can be fused into language pedagogy and theories of language acquisition? Third, what strategies do teachers should follow to reduce students' dependency on translation?

\section{LITERATURE REVIEW}

The relationship between language teaching and translation goes back a long time. The grammar-translation methodology forms one part of the other two macro-methodological approaches, namely Audiolingual/audio-visual, and Communicative language teaching (Funk, 2012). The hegemony of grammar-translation "emphasised the written medium and the study of explicit grammar rules, gave way to new methods based on scientific accounts of language and well-established learning theory (i.e. behaviourism)" (Ellis, 2002, p. 4). The methodologies mentioned above have been proven of little benefit to the students, and the constant correction of errors has proven to play a role in demotivating the learners (Ellis, 2002, p. 4). These methods have been superseded by the communicative approach; the communicative approach itself has been challenged by 'blended learning', where online learning espouses face to face learning. These changes and challenges in language teaching methodologies have instigated the birth of TAFL (Teaching Arabic as a Foreign Language) and TASL (Teaching Arabic as a Second Language) studies. While TAFL has been conceptualised and developed mainly outside Arab lands, the TASL is treated in the Arab-speaking world and focus more on the learner and learning process (Alhawary, 2009).

It is significant to stress the difference between these two approaches, particularly with Arabic, as learning Arabic as a foreign language has strong implication to the significance of the students' exposure to the language. According to Stevens (2006), AFL students need more additional teaching hours to attain proficiency. Students often comment on the lack of opportunity to use their language skills in the community.

The term SLA, when applied to Arabic, presents numerous problems, as Arab scholars are divided in defining it because of the existence of various Arabic varieties and the perennial problem of diglossia. Some scholars consider MSA as a mother tongue, while others see it as second language because of the wide gap between the colloquial form and the standard (Facchin, 2017). However, SLA studies in its 'pure' form follow three tendencies:

(1) a general move from description to explanation of L2 acquisition, (2) the widening of the frame of reference from the study of how learners acquire grammatical competence to how they acquire a knowledge of the pragmatic rules of an L2, and (3) the establishment of SLA as a relatively autonomous subdiscipline of applied linguistics and a concurrent lessening of interest in its application to language teaching (Ellis, 2002, p. 5).

SLA studies and theories have helped improve language teaching methodology through a move from "research then theory" to "theory then research" (Reynolds 1971, cited in Long (1985). This shift has generated significant theories in SLA such as the role of input in Krashen's Monitor Model, and Pienemann's (1989; 1998; 2005) Processability Theory (PT) where the latter stresses that teaching should be based only on those language structures the student can process, and are produced "according to a particular developmental hierarchy in which learners are unable to produce a structure belonging to a particular stage if they cannot produce structures belonging to a lower stage in the hierarchy" (Al Shatter, 2011, p. 128). Other SLA theories such as the focus on the needs of the learner (Doughty 2003), and what the learner observes or notices in the target language under the umbrella of "Noticing Hypothesis" (Al Shatter, 2011, p. 128).

However, the changes in language teaching and learning methodologies become closely related to the language learner's needs and aspirations. Besides the four macro-skills of speaking, reading, listening and writing, the language learner needs to possess the pragmatic skills of language and intercultural competence. Lack of these latter skills is evidenced through various examples of students' mishaps in their writing exercises. Though some elements of the pragmatic aspect of language are found in several resource books in Arabic such as Alosh and Clark's (2013) Ahlan Wa Sahlan, the variety and authenticity of these examples found in the book are still lacking depth and authenticity.

The teaching of Arabic always had its challenges. The Arabic language was classified by the USA Department of State in Category III or IV as "super hard languages" (Ryding, 2006, p. 15). Several substantial volumes have discussed the hurdles of teaching learning Arabic, such as the edited work of Wahba et al. (2006). Though the handbook covers a range of issues in the teaching of Arabic language such as 'diglossia', it fails to address the problems associated with the need to reconsider how translation should be introduced in creating Arabic resources. However, there is a consensus in several works in the volume, such as by Ditters (2006), Madhany (2006), and Stevens (2006) that using technology is inevitable in language acquisition. For instance, Ditters (2006, p. 242) points out that 'man-machine' communication has made giant leaps in both software and hardware development from 'terminals linked to mainframes' in the 70s to personal computers in the 80s and the internet in the 90s. This development has helped to produce Arabic graphics and fonts to facilitate CALL (Computer Assisted Language Learning). Today, numerous software firms offer the teaching of Arabic online such as Declan, Rosetta, Aramedia, Quest, and Sakhr (Ditters, 2006, p. 245). However, Stevens (2006, p. 254) believes that "access in technology does not guarantee its use in language learning." For instance, 
overreliance on technology in text production may increase instances of plagiarism.

Conversely, Madhany (2006, p. 295-296) advocates that teachers should use computer software such as Office Word, e-mail and the Internet in Arabic. He supports these because:

These three prevailing applications is [sic] encouraged because they have currency in the general marketplace and face little threat of being supplanted (as opposed to being continually updated) by new technologies. All three have persisted for well over a decade now and even as they continue to improve in functionality and efficacy, they will grow to provide more and more options for the end user.

However, Madhany's claim that by the sheer learning of word processing skills in Arabic improves competency and proficiency is a far-fetched proposition. He asserts that through Word features such as the correction of spelling and the provision of synonyms can help students' language acquisition. Even though his findings are based on research that harks back to the 1990s and early 2000s, they still need to be re-qualified today, primarily when AFL students rely on online translations instead of word processing software.

However, about the teaching of Arabic, the reliance on the grammar-translation methodology is still ubiquitous today in Arabic textbooks. This is because "less commonly taught and researched languages are still basically taught and learned with an emphasis on grammar, while internationally more frequently taught languages such as English, German and French have progressed to a communicative approach with an emphasis on language production and a more implicit approach in the teaching of grammatical structures" (Funk, 2012, p.298).

One of the language's macro-skills is writing. It is a productive skill, which is one of the most challenging skills a student of AFL may experience. In terms of difficulty, according to Davies (1976), writing along with speaking belongs to 'stage 3' of knowledge of the foreign language. It is preceded by stage 1 (the receptive skill of reading) and stage 2 (the receptive aural skills) (Davies 1976). Davies (1976) advocates a push towards teaching the receptive skills more than the productive skills as he criticizes language courses which after three years of study, students lack reading skills.

In their book on pragmatics Thinking Arabic Translation: Course in Translation Method:Arabic to English, Dickins et al. (2002) have treated translation as a process engendered by the translator's 'strategic decisions' and 'decisions of details' (Dickins et al. 2002, p. 6-7). By strategic decisions, the authors propose that the translator considers both linguistic and extra-linguistic characteristics of the ST, effect and genre. These 'decisions details' refer to the translator's reasoning when encountering translation problems with the ST's lexico-grammar. These translation problems have attracted a plethora of studies trying to account for the translator's 'pitfalls or 'errors'. A few researchers have provided criticism of the current practices in assessing the translator's performance, such as Hatim (2013) and Nord (1991). Hatim (2013) questions the validity and reliability of the assessment and performance tools utilized in assessing translation. The 'yard-stick' used to assess performance "becomes an all-or-nothing category, applied against some undefined absolute standard instead of responses being judged in terms of degrees of acceptability for particular purposes" (Hatim and Mason, 1997, p. 165). There is also a distinction between "translation quality assessment" and "translator performance assessment", where the focus should be on the skills taught such as how to handle a specific task and "audience design" (Hatim and Mason, 1997, p. 170).

However, the discussion thus far is based on the observations and inferences from students of translation viewpoint, who are learning about translation methodologies, not from the amateur translator's perspective.

The analysis of amateur translations alludes to Izwaini's (2012) work which examined amateur translations on Social Media. His findings indicate that the translations are generally poor in quality. Sometimes, he points out that these translations can be 'fake' aiming at amusement and are generally conducted in the colloquial form of Arabic (2012, p. 98). What complicates assessing the quality of translation, especially in social media and particularly with subtitling, is what Izwaini (2012) calls "relay subtitling" when the amateur translator does not mention the ST when translated to the 'first' TT (Target Text) and then into Arabic.

Parallel to amateur translations as discussed by Izwaini (2012), lack of quality of translation is found in MT. MT refers to the "process that utilizes computer software to translate text from one natural language to another. This definition involves accounting for the grammatical structure of each language and using rules, examples and grammars to transfer the grammatical structure of the source language into the target language (TL)" (Alawneh et al. 2011, p. 95). Alwaneh et al.'s research of MT from English into Arabic is based on the sentential level. The problem areas in MT include and not restricted to the adjective-noun agreement, verb-subject agreement, and pronouns. These grammatical areas always cause a problem for non-native speakers of Arabic.

Correct translation hinges heavily on the students" awareness of the significance of morpho-syntax in Semitic languages where there is an intimate relationship between morphology and semantics. According to Almanna (2016, p. 38), "translators need to pay extra attention to these semantically related Arabic words to avoid confusion that they may cause as they sometimes lend themselves to morphologically unrelated words." For instance, kataba 'he wrote' vs. $k \bar{a} t a b a$ 'he corresponds', qatala 'to kill' vs. qattala 'to massacre'.

The few instances when the students learn about the link between morphology and meaning, it was like a revelation, as confirmed by Almanna (2016, p. 38). This is because only a few resources in Arabic offer explanations about the subtleties of the Arabic language, let alone translation.

This paper identifies areas of difficulty in learning AFL on both lexical and sentential levels. It argues for the teaching of essential skills of translation as evidence suggests students' overreliance on translation through MT and 
other software applications.

\section{THEORETICAL FRAMEWORK}

The significance of translation in academic discourses has produced a plethora of studies in all aspects of translation theories and practices. ${ }^{b}$ However, the connection between language teaching and translation is still understudied. Perhaps, the areas that both disciplines share are error analysis in both translation and writing, as a productive skill in language learning acquisition. Since the paper focuses on the translation mishaps when writing in Arabic, it is of relevance to the study to conceptualise the underpinnings of these errors.

One of the significant criticisms of testing translation performance is that "all the skills are tested at once and errors do not necessarily show which skill is deficient" (Hatim and Mason, 1997, p. 165). Few researchers have analysed translation errors, including Gouadec (1981) and Sager (1983).

In the present paper the source text (ST) is not available, as the students produce a text in Arabic with or without the assistance of MT, which is one difficulty of error analysis. However, based on Sager's (1983) work, errors are classified in these areas, namely inversion of meaning, omission, addition, deviation, and modification. This is summarized into three macro-levels, which are linguistic, semantic, and pragmatic (as cited in Hatim and Mason, 1997, p. 168). The most essential part of translation is reflecting on the message intended by the original text producer. Therefore, changing the verbs used in the original text, or adding, deleting, or changing the semantic roles filled by these arguments, will create slightly or different mental images and messages.

Theoretical considerations are part of the makeups of language teaching pedagogy. These are viewed from different perspectives. The focus can be guided by three approaches, namely focus on 'forms', 'meaning, and 'form' (Long, 1997). Focus on forms occurs when the teacher or course syllabus introduces the grammatical aspects of language in terms of 'frequency', 'valency', and 'difficulty'. With these in place, the leaner navigates intuitively through the syllabus to take in those aspects used for the communicative purpose. Conversely, focus on meaning deals with the learner and learning process and not the language per se, and the focus is "purely communicative" (Long, 1997, para. 11). Under this model, the teaching of grammar is taught implicitly (Long, 1997, p.11). As for the 'focus on form', it refers to how attentional resources are allocated, and involves briefly drawing students' attention to linguistic elements (words, collocations, grammatical structures, pragmatic patterns, and so on), in context, as they arise incidentally in lessons whose overriding focus is on meaning, or communication, the temporary shifts in focal attention being triggered by students' comprehension or production problems (Long, 1997, para. 17).

Reliance on translation methods used to be part of teaching methodology, but the new move to the communicative approach to languages has reduced the place of translation in language teaching methodologies. Translation, like any other disciplines, can be taught and "is no different from aptitude for any other activity: teaching and practice help anyone, including the most gifted, to perform at a higher level” (Dickins et al., 2002, p. 1).

The theoretical considerations that apply to the current study are interlinear and literal translations, free translation, communicative translation and equivalence. Interlinear translation refers to those grammatical units that correspond closely to every grammatical unit of the ST (Dickins et al.2002, p. 15). Interlinear translation is an extreme form of the much more common literal translation (p. 16). Free translation refers to the maximum TL bias (p. 16). The following chart adapted from Dickins et al. (2002) summarises the continuum of translation as it contains the degrees of freedom in translation. It embodies 'bias' towards the SL text in its extreme literal adaptation or bias toward the SL text in its most free aspect of translation, as shown below:

\begin{tabular}{|l|l|l|l|l|}
\hline SL bias & Faithful & $\begin{array}{l}\text { Balanced } \\
\text { (SL/TL) }\end{array}$ & Idiomizing & TL bias \\
\hline Literal & \multicolumn{2}{|c|}{\begin{tabular}{l} 
Free \\
\hline
\end{tabular}}
\end{tabular}

Figure 1. Translation continuum (based on dickins et al., 2002, p. 16)

As for idiomizing translation, it follows the principle of free translation because it favours the naturalness' over 'faithfulness' to the TL. Under this strategy, idiomizing translation uses idioms with rhythmic patterns to enhance or ameliorate the readability of the text even if the translation "sacrifices nuances of meaning or tone" (Dickins et al., 2002, p. 18).

The following example from Dickins et al., (2002, p. 18) illustrates the above-mentioned translation strategies:

مثل هذه الأثياء عليها إقبال كثير الآن

Interlinear Like these things to them demand much now.

Literal The likes of these things have much demand now.

Faithful Things like these are in great demand now.

Balanced This kind of thing's in great demand at the moment.

Idiomizing This type's all the rage

Free This one's dead trendy

As for 'equivalence in translation', it can have two interpretations: descriptive and prescriptive. With descriptive

\footnotetext{
${ }^{\mathrm{b}}$ The research platform Academia records more than 12,000 research papers in the field of Arabic translation.
} 
equivalence, it "denotes the relationship between ST features and TT features that are seen as directly corresponding to one another, regardless of the quality of the TT" (Dickins et al., 2002, p. 19). For instance:

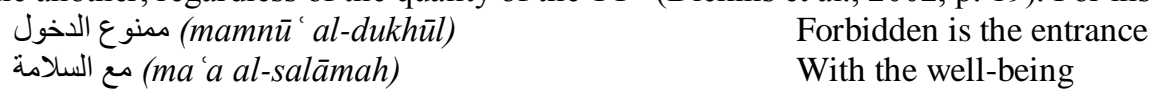

In contrast with descriptive equivalence, prescriptive equivalence "denotes the relationship between an SL expression and the canonic TL rendering of it as required, for example by a teacher" (Dickins et al., 2002, p. 19). So the following are equivalents:

$$
\begin{array}{ll}
\text { مع السلامة الدخولة } & \text { no entry } \\
\text { منول } & \text { goodbye }
\end{array}
$$

As for 'dynamic equivalence' or 'prescriptive equivalence', it hinges on the promise of 'the equivalent effect'. It is related to the communicative translation where "that is just the way we would say it" (Nida, 1964, p. 159).

Linguistic competence is not the only criteria to characterize an effective communicator or translator Galloway (as cited in Al-Batal, 1988, p. 443) stresses that "the ability to communicate in another language requires not only knowledge of the grammatical system of a language but knowledge of the patterns of living, acting, reacting, seeing, and explaining the world of the target country as well." Hewson (1995) complements good translation with 'cultural competence', which is a significant element in achieving quality translation. This is supplemented by the work of Nord (1991) who proposes 'transfer' and 'factual and research' competence as significant criteria of a good translator.

One of the most encompassing approaches in the theory of a good translation is put forward by Bachman (1990) who devised a taxonomy of competence into 'organizational competence' which incorporates grammatical and textual competence, pragmatic competence, and strategic competence where the translator assesses suitability and efficacy of the translation.

Curbing translation mishaps can only occur if efforts are made to re-think about how to fuse good translation practices as not only an integral part of the productive skill of writing, but as an additional skill that links reading, writing and other language skills such as pragmatic and cultural competence. This is conceptualized in the following figure:

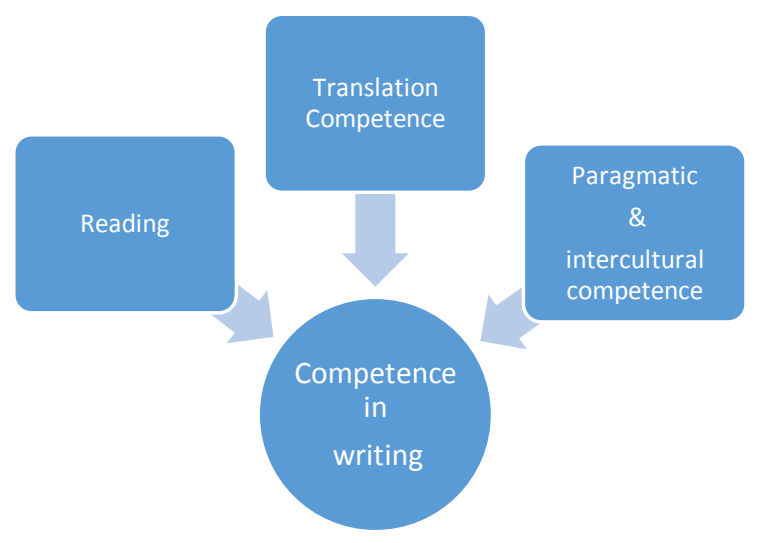

Figure 2. Relationship of translation with other skills

This above-mentioned theoretical précis of translation emphasizes the significance of reflecting on the possibilities and constraints of translation in text production. The students' lack of knowledge on the complexities and subtleties of translation needs to be considered by implementing the teaching the rudiments of translation theory so students are not fettered by the biased end of the translation spectrum; their familiarity with much translation gives them the freedom of choice. This paper adopts a fresh approach to translation by advocating the marriage between theories of language teaching methodologies and translation studies.

\section{Methodology}

The analysis is based on both primary data and secondary data and uses quantitative and qualitative methods. The primary data consists of the students' writing tasks stored on the University cloud system. Around 10-20 texts will be downloaded from twenty students.

The informants are non-native speakers of Arabic at an Australian university. For ethical clearance purposes, the selected students have completed their studies in Arabic to avoid issues of conflict of interest. Students have answered a brief questionnaire detailing their use of online translation tools when writing in Arabic (see appendix A). The questionnaire comprises four questions, one of which is an open-ended question: How do you think the translation online tools have helped or hindered your acquisition of Arabic? Any personal reflections about the translation process in language learning. 
Each student contributes one or two texts (written assignments). The texts' content varies in themes. One of the main texts used in the analysis requires the students to write a narrative on a short video and with no sound entitled 'The Black Hole' about greed. All submitted texts will be analysed for errors. Identified errors will be judged whether Google translation has been used in the writing process by back translation (translated back into English) using Google translation, and compare the translation with the students' texts.

The findings of this research will directly affect the teaching methodology of Arabic and other languages. If the findings indicate that Google translation is extensively being used in the students' writing, then it is vital to integrate translation methodologies as part of the teaching process. One cannot follow the proverbial ostrich of burying one's head in the sand and pretend that the problem does not exist, or that students would follow the teacher's advice by not relying on MT. Notwithstanding its perils, MT is immediate, practical and a quick fix. However, students need to understand that the translation process is not just mechanical; but requires understanding and appreciation of language complexities and subtleties in morpho-syntax, semantics, stylistics, pragmatics, and rhetoric.

\section{RESUlTS AND DisCUSSION}

The analysis of the students' translations confirms the survey findings that online translation has been used in writing. A close examination of the texts reveals translation problems on most levels of language: grammatically, lexically, and pragmatically. In this section, the students' surveys will be first analysed, followed by error analysis found in their translations. This section is followed by a discussion on the feasibility of translation in acquiring AFL.

\section{The Students' SuRvey Results}

The survey shows that all students have confirmed using MT as a strategy in the writing process. More than half the students $(60 \%)$ use sentence level-translation with $40 \%$ of students use lexical or dictionary level based translations. In terms of how helpful these practices are, most agree that they find it helpful with (80\%) and only (20\%) of respondents found it as 'least helpful'. However, the open-ended question reveals interesting responses. Some students express regret relying almost too heavily on translation as candidly expressed by Peter that:

In the past I have been used Google Translate as a shortcut to mastering [the] grammatical structure and doing so has hindered my language acquisition. Online translation tools provide instant results at the expense of accuracy, and genuine linguistic competency. There is no substitute for the traditional method of paced mastery through exposure, repetition, and systematic rehearsal.

This student's 'regret' also echoes other respondents such as by this female student "I regret not accessing dictionaries instead of online translation for chunks of text."

Other students have expressed that they resort to translation when they feel rushed, but they know the imperfections of the online translation services.

What is more revealing is provided by the following student whose 'honest' input show that relying on online translation hinders learning, and even when students acquire new vocabulary via the translation process is forgotten in a matter of hours, as stated by Peter ${ }^{c}$ :

I often read my previous assignments and find sometimes I don't even understand a quarter of what I have written in Arabic. I think this is because when you use Google translate you can add as many new words to your assignment as possible. The result is that you overloaded yourself with new vocabulary and you simply forget many of this in a matter of days or even hours. It also hinders to remember how certain words are spelt in Arabic, as I simply type a word in English and copy the Arabic spelling into my assignment without thinking about how the word sounds or spelt. Therefore, you have not given yourself the opportunity to sit down, reflect and understand what you're writing about whether that is sentence construction or spelling.

\section{ANALysis OF THE StUdENTS' TRANSLATIONS}

The analysis of the students' translation reveals interesting findings on both lexical and sentential levels. There are instances of stylistic errors; errors that are not ungrammatical but those that rarely make sense in the TL.

Lexical Level

There are many instances of incorrect lexical translation from English to Arabic. ${ }^{\mathrm{d}}$ Because most students use MT instead of dictionaries, they are satisfied with the first translations offered by MT. One good example of an incorrect translation is the word 'busy'. It is probably the most common error in the students' translations from English to Arabic. In Arabic, its use depends on sentential contexts. Here is an example of a student translation (StT) followed by a Google translation (GT):

(1)

(StT) kāna Lubnān mašghūl wa mulawwan

(GT) Lubnān machghūl wa mulawwan

\footnotetext{
c A pseudonym.

${ }^{\mathrm{d}}$ For more examples, see Appendix B.
} 
(ST) 'Lebanon was busy and colourful'

In the example above, the StT has clearly adopted the Google alternative despite the absence of the verb kāna 'was' in GT.

In MSA, the word (مشغولmašg̀ $\bar{u} l$ ) comes from the root base < šgl > with its generic gloss 'occupied', but it has many contextual uses, such as baytun mašğ $\bar{u} l$ 'an occupied house'; mašğ $\bar{u} l$ al-bēl 'an occupied mind'; hātef mašğ $\bar{l} l$ 'the phone is busy'. However, there are no adjectives used to modify countries or streets. Regarding 'a busy street', while it is accepted in English, in Arabic the accepted translation for 'a busy street' is šâri'un moktaddun. As for the word mulawwan 'colourful', it is not clear what the students have intended to mean, whether it is meant 'multicultural' or a country that provides interesting touristic destinations.

Another word is (قديمة qadimah), which is misused in the following sentence:

(2)

(StT) kāna 'mra'ah qadìma wa badawiy min al-jibāl fil al-janūb

(GT) kānat 'mra'atan 'ajūz wal-badw min al-jibāl fi al-janūb

[kānat 'mra'atan 'ajūz wa badawiyyah min al-jibāl fil al-janūb]

(ST) 'She was an old Bedouin from the mountains in the south'

In the example (2) above, the student might have used Google translation. Besides the verb-subject agreement error ( $k \bar{a} n a$ instead of kānat), the choice of qadīmah instead of 'ajūz indicates that the student does not know the different uses of the word 'old'.

Sentential level: Interlineal and Literal Translations

Here are examples taken from the students' work, which demonstrates the students' reliance on Interlineal and Literal translations:

(3)

( St.T) 'asna u mawāqi 'an wa tațbīq hātif

(GT) 'aqūm bi 'amal mawāqi 'wa tațbīqāt hatifiyyah

(ST) 'I create websites and phone applications'

(4)

(StT) 'a 'malu ma 'a šarikāt kibār wa šarikāt șiḡār

(GT) 'ana 'a 'mal ma 'e al-šarikāt al-kabīrah w al šarikāt al-sà̃̄irah

(ST) 'I work in big and small companies'

In example (3) and (4), GT has performed better than the student's work. The student may not have used Google translation. In example (4), the student made a grammatical error in the noun + adjective agreement where the adjective was chosen as a plural masculine; it should have been singular feminine as it modifies a singular inanimate noun.

(5)

(StT) al-farq al-kabīr fi al-maḍar al-jasadi huwa 'anna al-'anawīn al-ra '̄siyyah ġāliban ma takūnān zāhiyah mithla al-akhdar al-telegraph l-i-lqișaș fi dā iman b al-lawn al-aswad.

(GT) al-firaq al-kabīr fi al-maḍhir al-mādī huwa 'anna al- 'anawīn al-ra' ’̄siyyah ġāliban ma takūn mulawanatan mithl al-lawn al-' 'akhdar l-il-Telegraph kama fi al-qișaș, fa hiyye dā'iman bi-al-lawn al-' aswad.

(ST) 'The big difference in the physical appearance is that the main headings are mostly colourful like the colour green for telegraph as for the stories, they are always in black'

In example 5, there are similarities between the two versions except the word zāhiyah 'colourfoul', which is unexpected use knowing the level of this particular student. However, both translations are inaccurate with the term 'appearance'; it should be translated as 'al-maḍhar al-khārij̄ì'.

(6)

(StT) hatta dhahart fikra fi 3aqlihi

(GT) jā' at fikrat 'ilā dhihnihi

[jālat bikhāirihi fikrah]

(ST) 'An idea came to his mind'

(7)

(StT) machā al-qițt jamīl

(GT) mašā al-qiț̣ latīf

[machaa al-qittu birašāqatin]

(ST) 'The cat walked nicely'

(8)

(StT) 'jabna al šawāre 'al-jumalā wa al-akl hunāka kāna ladhīdh

(GT) 'ahbabt al-šawāri 'al-jamīlah w al-ta' à kāna hunāka latīf

['ajabatni al-šawāri' al-jamīlah wa al-aklu hunāka kāna lațīfan]

(ST) 'I liked the nice streets and the food there was nice'

(9)

(StT) al-dākhili jamiilatun jiddan wa al-akbar tharā' fil al- 'ālam

(GT) al-dākhil jamīl jiddan wa mutrif fi al-'ālam 
[dākhilu al-masjidi jamīllun jiddan wa-al akbar fi al-'ālam]

(ST) 'The inside is most beautiful and luxurious in the world'.

Pragmatic competence

Pragmatic competence forms an integral part of the communicative approach. Not giving its true place in language teaching and learning design may cause significant misunderstandings, because when 'pragmatic failure' occurs, it is a sign that the message is misunderstood (Thomas, 1983, p. 91). Thomas (1983) sees pragmatic competence as encompassing other skills such as "grammatical, psycholinguistic, and social competence" (Thomas, 1983, p. 92).

Failure to consider how the TL works may exacerbate message ambiguity. Many cases of these are found in the students' writings. What is more frustrating from the teacher's perspective, when correcting such works, is to guess the students" possible versions of the ST. Instances of lack of pragmatic competence include:

(10)

(StT) tarakatnī sayyārat al-ojra fi mahatah

(GT) tarakatni sayarat al 'ujrat fi mahatat alhafilat

[nazaltu min sayyārat al-ojra fi mahattat al-hạfilah]

(ST) 'The taxi left me at the bus stop'

$(11)$

(StT) akhdhatni al-riḥla țiwāala al-yawm

(GT) al-riḥla takhudhuni tawāl al-yawm

[istagraqat al-rihlah kulla al-yawm]

(ST) 'The trip took all day'

In example (10) and (11) above, the verb taraka 'to leave' and akhadha 'to take' cannot be used with inanimate subjects like 'a car' and 'a trip', respectively. This demonstrates that students lack pragmatic competence, which can be compensated by reading widely in Arabic. Reading can help the students learn formulaic expressions in Arabic, metaphors, and rhetoric which is "the flesh and blood of the Arabic language. It is a linguistic discipline that aims to sharpen up and upgrade the linguistic competence of writing and speaking” (Abdul-Raof, 2006, p. 1).

Students' reliance on translation tools is beneficial when executed with good knowledge of SL and TL, and framed by a good understanding of translation strategies and practices. There is no perceived harm when a student searches for the meaning of a word in 'good' dictionaries such as Hans Wehr's one.

However, the main concern of language teachers with the students' performance is when the students' intended message is lost in translation. Loss in translation is astutely defined by Dickins et al., (2002, p. 21) as the "incomplete replication of the ST in the TT - that is, the inevitable loss of textually and culturally relevant features." Dickins et al. (2002) point out that translation should be understood as a loss during the process of translation not when the task is finalised, or rather "loss of textual effects". They add that translators should aim at reducing translation loss, and not being fixated pursuing the ultimate TT (Dickins et al., 2002, p. 21).

Translation loss can take different forms: phonic/prosodic and more serious semantical. For instance, the translation of the word to 'intifada' has lost the Arabic phoneme (d- ض) which is an example of a phonic loss. This loss is explained by Dickins et al as "a loss of the cultural neutrality of the ST expression" (Dickins et al., 2002, p. 21). Translation loss can be interpreted in terms of equivalence loss as either by omission or addition, and "if translation loss is inevitable even in translating single words, it is obviously going to feature at more complex levels as well - in respect of connotations, for example, or of sentence structure, discourse, language variety, and so on" (Dickins et al., 2002, p. 23). Omission can be a legitimate strategy, as often in Arabic, some expressions are omitted when translated into English (Dickins et al., 2002). For instance, the expression jadīr bidhdhikr 'it is worth mentioning' is a precursor expression for something about to provide "background information".

Conversely, the translation by addition occurs when something is added to the TT when translating the ST, for example, if one translates sentences mundhu al-haymanah al-Turkiyyah there are two translations for this, namely "ever since the days of Turkish hegemony" (Ives cited in Dickins et al., 2002, p. 24) than as "ever since Turkish hegemony" ("time of Turkish hegemony"- would also be possible). In the English language, it is necessary to add "days of" in the TT.

The students' reliance on Google translation is evident when the correct cultural term is unknown. For instance, the correct word $a l$ - 'âdhān 'call for prayer' is translated by the student as da'wa 'ila al-șaläh, which is a Google translation for 'call for prayer'.

Semantic transfer from L1 to L2 production is evident in numerous examples, as shown in the Appendix B, when for instance expressions such as tarakatni sayyārat al-'ojrah fi mahatat al-bās 'the taxi left me at the bus stop' cannot be used in MSA, while it is semantically acceptable in English.

\section{TEACHER's STRATEGIES}

In the following section, I propose some writing strategies that have worked with my students of Arabic. Before outlining these strategies, it is essential to emphasise that the writing tasks should find a balance between 'guided' tasks and 'creativity'. Here are four strategies:

Strategy 1. 
From the very beginning of the course, the teacher should outline both the advantages and disadvantages of relying on translation such as Google translation. The teacher should provide examples of incorrect translations.

Strategy 2.

The teacher should outline some rudiments of the translation practices and strategies, by explaining the differences, such as between literal and semantic translation.

Strategy 3.

While it is important to encourage creative writing, it is important to encourage students to use the learned structures first before moving to use complex structures, which are beyond their level of language acquisition.

Strategy 4.

As discussed earlier many students desire to jump stages of language learning to either impress the teacher or to score a higher mark. Teachers need to clarify to the students that committing errors is part of the learning process.

In summary, the strategies mentioned above may not work with every language practitioner. However, educating the students about the translation process plays a significant role in raising awareness about the perils of 'bad' translation. Translation remains a pedagogical tool that cannot be overlooked, especially when it is equipped with an appealing technology at the fingertips of the language learners.

\section{CONCLUSION}

The paper demonstrates through numerous instances that Google translation and possibly other software applications, grouped under the rubric of MT, are used in the productive skill of writing. The AFL students' overreliance on MT is symptomatic of a deeper problem in the teaching pedagogy and methodology.

Notwithstanding the theoretical and empirical studies in both AFL and SLA in framing how languages should be taught, these face challenges against technological challenges, such as the ubiquitous software applications. The dilemma arises when a student, say at stage 1 of language learning can, by a mere mouse click, jump into higher levels, and hence ignores all language learning models such as developmental and comprehensible input theories.

In attenuating the negative side of MT, the paper suggests that the teaching of AFL should include the teaching of the rudiments of translation. This does not suggest that the communicative approach should be abandoned to embrace the grammar-translation method. It is not all or nothing, far from it. However, teaching methodologies should renew itself by being more pragmatic and in-tune with technological advances. The students should be educated about translation, and hence symbiotically making it related to learning. Failure to do so would cause the students' reliance on the biased literal interpretation of the ST, which may expose them or others to the 'dangers' of loss in translation. The paper remains a child-first-step into rethinking translation in the teaching of languages, and research in this area should continue to face the challenges of today's technological advances.

\section{ApPENDix A. Survey Questions (Translation)}

1. Have you ever used Google translation or any other software for your writing tasks in Arabic? (Please circle)

YES NO

If YES, how often:

$\begin{array}{lll}\text { Always } & \text { Often } & \text { Sometimes }\end{array}$

2. If you use Google translation or other software/word/phone applications, how do you use it?

(Please circle what relevant to you)

As a dictionary (word level) Translating (sentence level) Translating (paragraph level)

3. How helpful do you find the translation overall?

Least helpful unsure helpful very helpful

4. Open-ended question: How do you think the translation online tools have helped or hindered YOUR acquisition of Arabic? Any personal reflections about the translation process in language learning. 
APPENDiX B. LEXICAL/SEMANTIC TRANSFER/INCORRECT TRANSLATION

\begin{tabular}{|c|c|c|c|}
\hline $\begin{array}{l}\text { Lexical/Semantic } \\
\text { Transfer/Incorrect } \\
\text { Translation }\end{array}$ & Source Text (ST) & St.T (Student translation) & Commentary/Correction \\
\hline & My suburb & بلدي الضاحية & Incorrect use of the word 'suburb'. \\
\hline & It is too late & بات الوقت متأخر ا & $\begin{array}{l}\text { Incorrect use of the verb bāta } \\
\text { 'became' }\end{array}$ \\
\hline & $\begin{array}{l}\text { Soon after having tea at (sic.) } \\
\text { about noon }\end{array}$ & قريبا بعد ان تناولت الشاي عند الظهر & $\begin{array}{l}\text { Structural issue with the adverb } \\
\text { uses of qarīban 'nearly' and } b a \text { ' } d a \\
\text { 'after' }\end{array}$ \\
\hline & Pale blue & زرقاء شاحبة & \\
\hline & $\begin{array}{l}\text { My imagination should fill in } \\
\text { the holes in the guide's story }\end{array}$ & 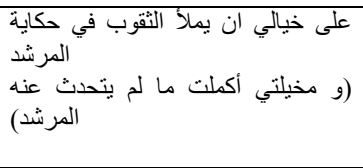 & $\begin{array}{l}\text { This sentence does not make } \\
\text { sense. It is a literal translation } \\
\text { from English. The correct sentence } \\
\text { is: } \\
\text { و مخيلتي أكملت ما لم بتحدث عنه المرشد. }\end{array}$ \\
\hline & Big jobs & وظائف كبيرة & $\begin{array}{l}\text { Incorrect use of wadhä'if } \\
\text { 'professions", the correct } \\
\text { alternative is: (المشاريع الكبرى) }\end{array}$ \\
\hline & In the museum interior & $\begin{array}{l}\text { (في داخله) } \\
\text { فياطنه }\end{array}$ & $\begin{array}{l}\text { Incorrect contextualised use of the } \\
\text { word bātin 'inside', the alternative } \\
\text { is (في داخله) }\end{array}$ \\
\hline & $\begin{array}{l}\text { The taxi left me at the bus } \\
\text { stop }\end{array}$ & تركتني سبارة الأجرة في محطة الباص & $\begin{array}{l}\text { In these two examples, both the } \\
\text { sayyära 'car' and rihla 'trip' were }\end{array}$ \\
\hline & The trip took me all day & أخذتني الرحلة طو ال اليوم & $\begin{array}{l}\text { given human qualities, as these } \\
\text { two sentences are semantically } \\
\text { unacceptable in Arabic. Here the } \\
\text { student uses semantic transfer } \\
\text { from L1 (English) into L2 } \\
\text { (Arabic). }\end{array}$ \\
\hline
\end{tabular}

\section{REFERENCES}

[1] Abdul-Raof, H. (2006). Arabic rhetoric: A pragmatic analysis. London: Routledge.

[2] Al-Batal M. (1988). Towards cultural proficiency in Arabic. Foreign Language Annals 21.5, 443-453.

[3] Alhawary, M.T. (2009). Arabic second language acquisition of morphosyntax. New Haven: Yale University Press.

[4] Almanna, A. (2016). Semantics for translation students: Arabic-English-Arabic. Oxford: Peter Lang.

[5] Alosh, M. \& A. Clark (2013). Ahlan wa Sahlan: Functional modern Standard Arabic for intermediate learners. USA: Yale University Press.

[6] Al Shatter, G. (2011). Processability approach to Arabic 12 teaching and syllabus design. Australian Review of Applied Linguistics 34.2, 127 - 147.

[7] Bachman, L. (1990). Fundamental considerations in language testing. Oxford: Oxford University Press.

[8] Cheng, Yuh-show. (2002). Factors associated with foreign language writing anxiety. Foreign Language Annals 35.5, 647-656.

[9] Davies, Norman F. (1976). Receptive versus productive skills in foreign language learning. The Modern Language Journal $60.8,440-443$.

[10] Dickins, J., S. Hervey \& I. Higgins (2002). Thinking Arabic translation: A course in translation method: Arabic to English. London: Routledge.

[11] Ditters, E. (2006). Technologies for Arabic language teaching and learning. In K.M. Wahba, Z. Taha \& L. England (eds.), Handbook for Arabic language teaching professionals in the 21 st century Mahwah, N.J.: Lawrence Erlbaum Associates, 239252.

[12] Doughty, C. J. (2003). Instructed SLA: Constraints, compensation, and enhancement. Malden, MA: Blackwell

[13] Ellis, R. (1992). Second language acquisition \& language pedagogy. Clevedon: Multilingual Matters.

[14] Facchin, A. (2017). Teaching Arabic as a foreign language origins, developments and current directions (Doctoral Dissertation, Scuola Dottorale di Ateneo). http://dspace.unive.it/bitstream/handle/10579/10303/808568-1186377.pdf?sequence=2 (accessed 20/02/2020).

[15] Funk, H. (2012). Four models of language learning and acquisition and their methodological implications for textbook design. Electronic Journal of Foreign Language Teaching 9, Suppl. 1, 298-311. http://e-flt.nus.edu.sg/v9s12012/funk.pdf (accessed 20/04/2019).

[16] Gouadec, D. (1981). Paramètres pour l'Evaluation des deductions. Meta XXVI (2): 99-116.

[17] Halliday, M.A.K. (1985). Spoken and written language. Oxford: Oxford University Press.

[18] Hatim, B. (2013). Teaching and researching translation. Second Edition. London: Routledge.

[19] Hatim, B. \& I, Mason (1997). The translator as communicator. London: Routledge.

[20] Hewson, L. (1995). Detecting cultural shifts: Some notes on translation assessment. In Mason \& C. Pagnoulle (eds.), CrossWords. Issues and Debates in Literary and Non-literary Translating. Liège: L3 - Liège Language and Literature, 101-108.

[21] Holes, C. (2004). Modern Arabic structures, functions, and varieties. Washington: Georgetown University Press.

[22] Krashen, S. (1977). The monitor model for adult second language performance. In M. Burt, H. Dulay \& M. Finocchiaro (eds.), viewpoints on English as a second language. New York: Regents, 152-161.

[23] Long, M.H. (1985). Input and second language acquisition theory. In S. Gass \& C. Madden (eds.), Input in Second Language 
Acquisition. Rowley, Mass: Newbury House, 377-393.

[24] Long, M.H. (1997). Focus on form in task-based language teaching. McGraw-Hill Companies. http://www.mhhe.com/socscience/foreignlang/top.htm (accessed 20/12/219).

[25] Madhany, A.L. (2006). Teaching Arabic with technology: word processing, e-mail, and the internet. In K.M. Wahba, Z. Taha \& L. England (eds.), Handbook for Arabic language teaching professionals in the 21st century. Mahwah, N.J.: Lawrence Erlbaum Associates Publishers, 295-304.

[26] Nida, E. (1964). Toward a science of translating. Leiden: Brill.

[27] Nord, C. (1991). Text analysis in translation. Amsterdam: Rodopi.

[28] Pienemann, M. (1989). Is language teachable? Psycholinguistic experiments and hypotheses. Applied Linguistics 10.1, 52-79.

[29] Pienemann, M. (1998). Language processing and second language development: Processability theory.Amsterdam: John Benjamins.

[30] Pienemann, M. (2005). An Introduction to Processability Theory. In M. Pienemann (ed.), Cross-linguistic aspects of processability theory. Amsterdam; Philadelphia: John Benjamins, ix-60.

[31] Ryding, K. C. (2006). Teaching Arabic in the United States. In K.M. Wahba, Z. Taha \& L. England (eds.), Handbook for Arabic language teaching professionals in the 21st century. Mahwah, N.J.: Lawrence Erlbaum Associates, 13-20.

[32] Sager, J.C. (1983). Quality and standards - the evaluation of translations. In C. Picken (ed.), The translator's handbook. London: Aslib, 121-128.

[33] Stevens, V. (2006). Learner strategies at the interface: Computer-assisted language learning meets. In K.M. Wahba, Z. Taha \& L. England (eds.), Handbook for Arabic language teaching professionals in the 21st century. Mahwah, N.J.: Lawrence Erlbaum Associates, 253-262.

[34] Thomas, J. (1983). Cross-cultural pragmatic failure. Applied Linguistics 4, 91-112.

[35] Ur, P. (1991). A course in language teaching: practice and theory. Cambridge: Cambridge University Press.

[36] Wahba, K. M., Z.A. Taha \& L. England (eds.) (2006). Handbook for Arabic language teaching professionals in the 21st century. Mahwah, N.J.: Lawrence Erlbaum Associates.

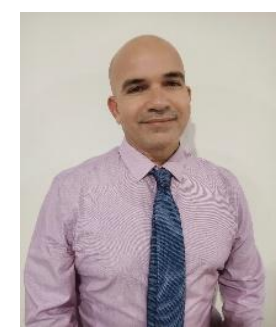

Zouhir Gabsi is a Senior Lecturer in Arabic and Islamic Studies at Deakin University, Melbourne, Australia. $\mathrm{He}$ has wide interests in research including language teaching, Berber Studies, and more recently Islamophobia, Arab Spring, youth identity and Islamic discourse. He has published several research articles on discourse and the Arab Spring. The most recent one being Rap and mizoued music: Claiming a space for dissent and protest in post-Arab Spring Tunisia published by Sociological Research Online. 